\title{
A SPECTRAL AGROMETEOROLOGICAL MODEL FOR ESTIMATING SOYBEAN GRAIN PRODUCTIVITY IN MATO GROSSO, BRAZIL
}

\author{
Christiany M. Sarmiento ${ }^{1 *}$, Priscila P. Coltri ${ }^{2}$, Marcelo de C. Alves ${ }^{1}$, Luiz G. de Carvalho ${ }^{1}$
}

${ }^{1 *}$ Corresponding author. Universidade Federal de Lavras/ Lavras - MG, Brasil.

E-mail: sarmientochristiany@gmail.com | ORCID ID: https://orcid.org/0000-0001-6264-3958

\section{KEYWORDS}

Geographic

Information System;

Mathematical

Modeling; Remote

Sensing;

Agrometeorology;

Crop Monitoring.

\begin{abstract}
This study used spectral data integrated with the agrometeorological model by Doorenbos and Kassam to estimate soybean grain productivity in the state of Mato Grosso, Brazil. In the developed model, spectral data were used instead of meteorological data and biophysical parameters of the crop. For this purpose, the products of real and potential evapotranspiration (MOD16), normalized difference vegetation index - NDVI (MOD13Q1), and leaf area index (MOD15A2H) from the MODIS satellite were used, in addition to sunstroke data obtained by using the visible channel from the satellite GOES IMAGER. The results obtained showed that, with the proposed methodology, it was possible to follow the development of soybean cultivation throughout the cycle and to estimate production and productivity in the study area. Willmott's agreement index was 0.99 and 0.96 and Pearson's correlation coefficient was 0.99 and 0.84 for production and productivity, respectively.
\end{abstract}

\section{INTRODUCTION}

Soybean (Glycine max (L.) Merr.] is one of the main agricultural crops in the world and Brazil, which is a leader in terms of productivity, stands out as one of the world's most important producers of soybeans (Artuzo et al., 2018). A quarter of national production is concentrated in the state of Mato Grosso, whose production is estimated to be at 113,923 million tons, according to the 2016/2017 harvest (CONAB, 2017).

The Brazilian estimates of soybean productivity essentially follow two axes: either by subjective methods (Gusso et al., 2017), which do not allow for a quantitative analysis of the errors involved (Rizzi \& Rudorff, 2007); or by a drop in yield based on agrometeorological models (Meshesha \& Abeje, 2018), which study the interaction between climate and productivity (Salimon \& Anderson, 2017; Gajić et al. 2018), seeking to quantify the effects of climate variations on plant behavior (Nascimento et al., 2018). In this context, there is a growing demand for methodologies that acquire productivity information and monitor large-scale soybean crops.
For many decades, mathematical models have been developed to characterize the effects of climatic variations on the development of soybean production, as demonstrated by Doorenbos \& Kassam (1979) and Lacasa et al. (2018), among others. However, most models need meteorological data and biophysical measurements collected in the field, which make it difficult to use them on a large-scale (Betbeder et al,, 2016; Gusso et al., 2017; Zeng et al., 2016).

More advanced tools need to be employed and the most promising techniques are spectral agrometeorological models, which combine agrometeorological models with spectral data obtained by satellite images (Betbeder et al., 2016). With advances in the science of remote sensing, these models have gained prominence by improving estimates of agricultural production (Ovando et al., 2018). In the case of soybean, knowledge on spectral behavior can characterize the different phases of phenological development (Mercante et al., 2012), as well as the acquire information on biophysical parameters, planted area, and productivity (Gusso et al., 2013), and, thus, are beneficial to crop monitoring.

As such, this study is based on the hypothesis that the integration of spectral data from high-resolution

\footnotetext{
${ }^{1}$ Universidade Federal de Lavras/ Lavras - MG, Brasil.

${ }^{2}$ Universidade Estadual de Campinas/ Campinas - SP, Brasil.

Area Editor: Jefferson Vieira José

Received in: 12-3-2018

Accepted in: 3-19-2020
} 
satellites with agrometeorological models is an efficient method for estimating soybean productivity. Thus, using soybean production clusters in the state of Mato Grosso as a case study, an agrometeorological-spectral model is presented that is capable of estimating soybean grain productivity in the study area. Additionally, this study verified the potential of high-resolution orbital data in monitoring the phenological dynamics of culture in the field between the period corresponding to harvest in 2012/2013.

\section{MATERIAL AND METHODS}

\section{Experimental Data}

The field experiment was conducted in soybean producing clusters in the state of Mato Grosso, Brazil, during the 2012/2013 harvest. The collection of productivity data was carried out on 10 plots located in the state of Mato Grosso, with a total area of 1,915.02 hectares (Figure 1).

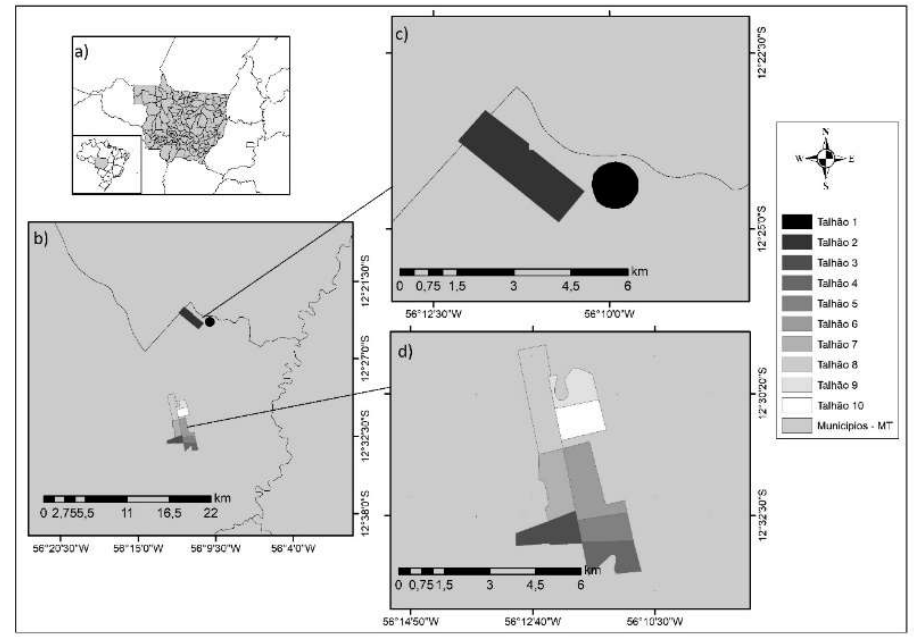

FIGURE 1. Study area. In (a), Mato Grosso is highlighted; in (b), location of the 10 plots in the field collection area are shown; in (c), plots 1 and 2 are highlighted, and in (d), plots from 3 to 10 are highlighted.

Information on the actual productivity and phenological stage were collected from the field in plots that were arranged and categorized according to date of planting (between 09/16/2012 and 09/21/2012) and the soybean cycle, which was divided into vegetative (V) and reproductive (R) stages (Fehr \& Caviness, 1977). Spectral information from satellites with a high resolution of the climate was acquired for the same period of cultivation in the field, between the Julian Day (JD) of sowing $(09 / 21 / 2012)$ and JD of harvest (01/17/2013), totaling a cycle of 120 days. At the end of this analysis, net production values collected in the field were obtained for each plot. These values were subsequently compared with the productivity estimated by the model for validation and analysis of model efficiency.

\section{Agrometeorological Model}

The model developed by Doorenbos and Kassam (1979) was adopted for estimating crop yield. In the soybean crop yield forecast model, Yp corresponds to the potential productivity of the analyzed crop and Yest is the actual production, estimated under optimal weather conditions, i.e. without water and/or thermal restraints. Mathematically, the model is defined by:

$$
\text { Yest }=\text { Yp }[1-\mathrm{ky}(1-\mathrm{ETr} / \mathrm{ETm})]
$$

Where:

$$
\begin{aligned}
& \mathrm{ky}=\text { productivity response factor; } \\
& \mathrm{ETr}=\text { real evapotranspiration, and } \\
& \mathrm{ETm}=\text { maximum evapotranspiration. }
\end{aligned}
$$

The estimation of potential crop productivity (Yp) was conducted by adopting the "Agro-ecological Zoning Method" (Doorenbos et al., Kassam, 1994). The potential productivity estimation model (YP) is expressed in [eq. (2)].

$$
\mathrm{Yp}=\mathrm{PPB}_{\mathrm{P}} \times \mathrm{C}_{\mathrm{LAI}} \times \mathrm{C}_{\mathrm{R}} \times \mathrm{C}_{\mathrm{C}} \times \mathrm{ND} \quad\left[\mathrm{kg} \mathrm{ha}^{-1}\right]
$$

Where:

$\mathrm{PPB}_{\mathrm{P}}=$ gross production potential of dry matter for the standard crop;

$\mathrm{C}_{\mathrm{LAI}}$ is the coefficient used to correct the leaf area index of the crop;

$\mathrm{C}_{\mathrm{R}}=$ coefficient used to correct crop maintenance respiration;

$\mathrm{C}_{\mathrm{C}}=$ correction for what was actually harvested, and

$\mathrm{ND}=$ number of days in the period analyzed. For $\mathrm{C}_{\mathrm{R}}$, a value of 0.5 was adopted for each JD because, according to reanalysis data from Merra-2, the average air temperature of the study area was higher than $20^{\circ} \mathrm{C}$ for all plots during the period analyzed.

The adopted harvest coefficient $(\mathrm{Cc})$ was 0.3 and the residual moisture content (U\%) was $8 \%$, since it is a nonirrigated area (Doorenbos \& Kassam, 1994). For soybean, there were 120 cycle days (ND) and $\mathrm{C}_{\mathrm{LAI}}$ was obtained by [eq. (3)], according to methodology by Battisti et al. (2013).

$$
\mathrm{C}_{\mathrm{LAI}}=\left(0.0093+0.185 \times \mathrm{LAI}-0.0175 \times \mathrm{LAI}^{2}\right)
$$

Where:

$\mathrm{C}_{\mathrm{IAF}}$ is the coefficient for correcting the leaf area index specific for the crop. 
The result of this equation assumes that the water, nutritional, and plant health requirements of the crop are met and that the yield is only conditioned by the characteristics of the crop and by the availability of solar radiation, photoperiod, and air temperature.

\section{Spectral Data}

To apply the agrometeorological model of Doorenbos \& Kassam (1979), data were used to introduce the spectral component, as described in Table 1.

TABLE 1. Spectral data used.

\begin{tabular}{|c|c|c|c|}
\hline Data source & Product & Specifications & Scene \\
\hline Terra/sensor MODIS & $\begin{array}{l}\text { Real evapotranspiration and potential } \\
\text { evapotranspiration (MOD16) }\end{array}$ & $\begin{array}{l}\text { Time Resolution: } 8 \text { days/Spatial } \\
\text { Resolution: } 1 \mathrm{~km}\end{array}$ & $\mathrm{~h} 12 \mathrm{v} 10$ \\
\hline DSA/CPTEC - INPE & $\begin{array}{l}\text { Hours of sunlight (n) obtained by GOES } \\
\text { Channel } 1 \\
\text { Imager }-0.55 \mu \mathrm{m} \text { (Sunshine hours) }\end{array}$ & $\begin{array}{l}\text { Time Resolution: Daily Spatial } \\
\text { Resolution: } 4 \mathrm{~km}\end{array}$ & $\begin{array}{c}\text { State of Mato } \\
\text { Grosso }\end{array}$ \\
\hline $\begin{array}{l}\text { Terra+Aqua sensor } \\
\text { MODIS }\end{array}$ & $\begin{array}{l}\text { Vegetation Index - NDVI } \\
\text { (MOD13Q1+MYD13Q1) }\end{array}$ & $\begin{array}{l}\text { Time Resolution: } 8 \text { days/Spatial } \\
\text { Resolution: } 250 \mathrm{~m}\end{array}$ & $\mathrm{~h} 12 \mathrm{v} 10$ \\
\hline Terra sensor MODIS & Leaf area index (MOD15A2H) & $\begin{array}{l}\text { Time Resolution: } 8 \text { days/Spatial } \\
\text { Resolution: } 1 \mathrm{~km}\end{array}$ & $\mathrm{H} 12 \mathrm{v} 10$ \\
\hline $\begin{array}{l}\text { Terra+Aqua sensor } \\
\text { MODIS }\end{array}$ & Pixel reliability (MOD13Q1+MYD13Q1) & $\begin{array}{l}\text { Pixel with value } 0=\text { Data able to be } \\
\text { used with confidence }\end{array}$ & $\mathrm{H} 12 \mathrm{v} 10$ \\
\hline Merra - 2 & Temperature & Daily temperature & Plot centroid \\
\hline
\end{tabular}

All acquired images were cut by using the shapefile of the 10 soybean plots for the 8-day interval corresponding to each JD, totaling 128 images, of which there were a temporal series of 16 images for each of the 8 spectral data in raster format (Table 1). The images were re-sampled using the nearest neighbor algorithm to standardize spatial resolution at $250 \mathrm{~m}$. In order to obtain data of higher quality and reliability and free of clouds, masks were created and applied using images from Pixel Reliability in order to preserve only pixels of value 1 , which were considered fit and reliable. All pixels contained in the plots were extracted, generating shapefiles made of points, according to the pixel value in the images corresponding to the plot limits. The variables related to real and potential evapotranspiration, derived from the MOD16 product, were used in the calculation of the penalty of potential productivity caused by water deficiency, instead of the equations proposed for calculation of real and potential evapotranspiration in the model by Doorenbos \& Kassam (1979).

\section{Temperature Data}

Daily temperature was acquired by the output from "Modern-Era Retrospective Analysis for Research and Applications" (MERRA-2) product (Table 1). The location of the pixel from MERRA-2 was identified according to the centroid of each plot in the study area and the data was extracted on a daily scale.

\section{Agrometeorological-Spectral Model}

Calculation of the agrometeorological-spectral model was performed by employing satellite images instead of field variables, wherein the images used were re-sampled for $250 \mathrm{~m}$ spatial resolution. The pixel values of each input variable were inserted into the agrometeorological-spectral model. After calculating productivity $\left(\mathrm{kg} \mathrm{ha}^{-1}\right)$ for each pixel inserted in the areas of coverage for each plot, productivity averages in $\mathrm{kg} /$ hectare were calculated for each Julian Day. The calculated productivity for each Julian Day was compared to the real productivity data obtained in the field.
To insert the spectral data into the agrometeorological model, the values of PPBp (potential gross dry matter production of the standard crop) were obtained by the sum of the potential productivity rates for clean sky (PPBc) and cloudy sky (PPBn) periods, according to eqs (4) and (5) developed by Pereira et al., (2007). PPBp was estimated every 8 days according to the time resolution of MODIS data throughout the cycle.

$$
\begin{aligned}
& \mathrm{PPBc}=[(107.2+8.604 \times \text { Qo }) \times \mathrm{cTc} \times \mathrm{n} / \mathrm{N}] \\
& \mathrm{PPBn}=[(31.7+5.234 \times \text { Qo }) \times \mathrm{cTn} \times(1-\mathrm{n} / \mathrm{N})]
\end{aligned}
$$

Where:

Qo is the global extraterrestrial solar irradiance in cal $\mathrm{cm}^{2} \mathrm{~d}^{-1}$;

cTc and cTn are correction factors for air temperature on light and cloudy sky days;

$\mathrm{n}$ is the daily sunshine hours per day, and

$\mathrm{N}$ is the maximum number of hours of daily sunlight (photoperiod).

To calculate the maximum evapotranspiration of the crop, [eq. (6)] by Doorenbos \& Kassam (1979) was used:

$$
\mathrm{ETc}=\mathrm{ETo} \times \mathrm{Kc}
$$

Where:

ETc is the crop evapotranspiration ( $\mathrm{mm} / 8$ days);

ETo is the reference evapotranspiration $(\mathrm{mm} / 8$ days), and

$\mathrm{Kc}$ is the crop coefficient.

Spectral information pertaining to the product MOD16A2 obtained by the Terra satellite was used to calculate evapotranspiration of the crop (ETc). The values for $\mathrm{kc}$ and $\mathrm{ky}$, productivity response factors, followed the methodology by Doorenbos \& Kassam (1979) (Table 2). 
TABLE 2. Crop coefficient $(\mathrm{Kc})$ and soybean productivity factor $(\mathrm{Ky})$ at various stages of development.

\begin{tabular}{cccccc}
\hline Crop & \multicolumn{5}{c}{ Stages of Crop Development } \\
\hline & I & II & III & IV & V \\
$\mathrm{kc}$ & $0.3-0.4$ & $0.7-0.8$ & $1.1-1.15$ & $0.7-0.8$ & $0.4-0.5$ \\
$\mathrm{ky}$ & 0.2 & 0.8 & 1.00 & & 0.85 \\
\hline
\end{tabular}

Source: Doorenbos \& Kassam (1979).

\section{Statistical analyses}

All statistical analyses were carried out on the trial software IBM Statistical Package for the Social Science (SPSS), taking into account the net production obtained in the field for the 10 plots examined and comparing it with a net output estimated by the agrometeorological-spectral model. The following statistical methods were adopted: linear regression, Pearson correlation, and Willmott's concordance index (Willmott et al., 1985).

\section{RESULTS AND DISCUSSION}

Monitoring of soy crops by spectral variables

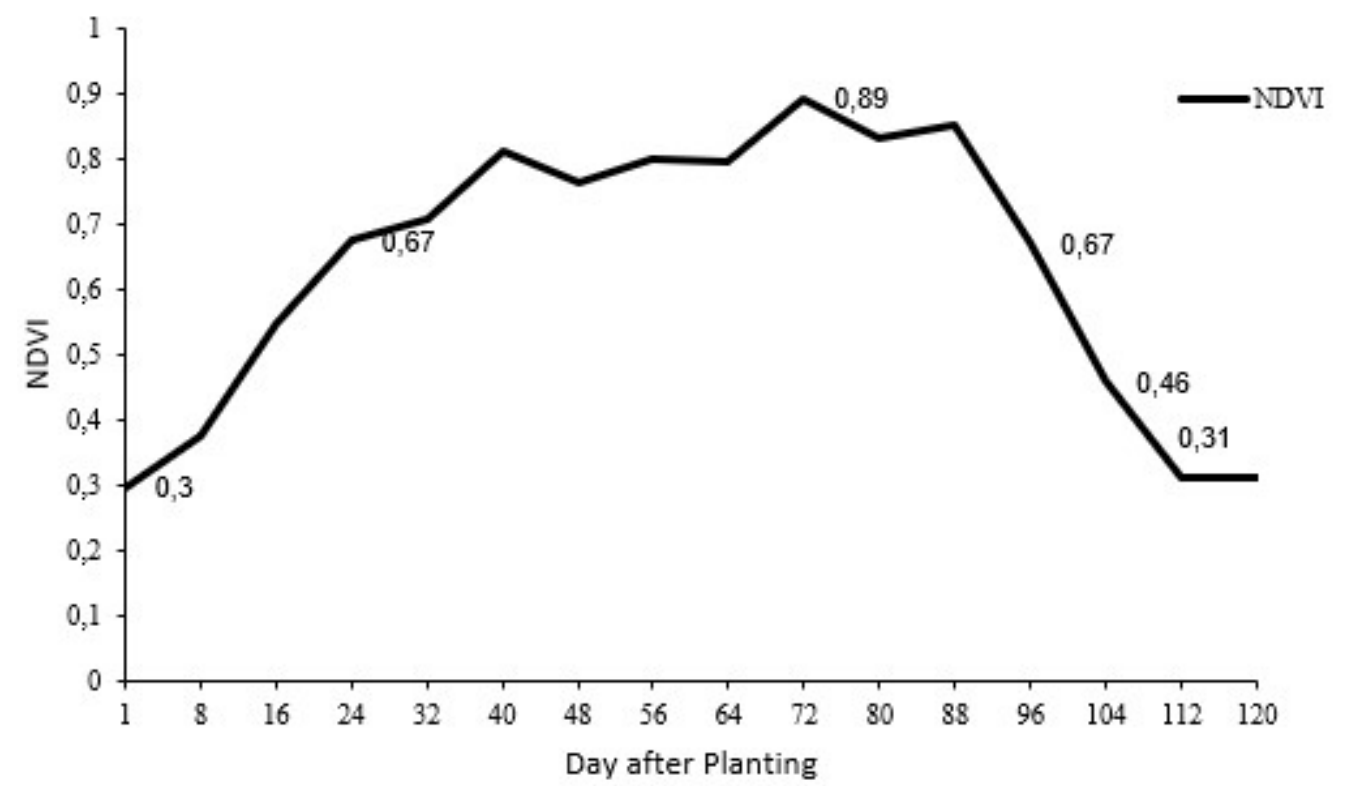

FIGURE 2. Spectral behavior of Normalized Difference Vegetation Index (NDVI) during the analysis period. The Y-axis is the NDVI values and the $\mathrm{X}$-axis is the day after planting.

Figure 2 shows the time evolution of the average Normalized Difference Vegetation Index (NDVI) on soybean in the 10 plots analyzed during the growing season of harvest 2012/2013. The NDVI variation is related to the phenological stages of soybean. Low NDVI values were observed at the beginning and end of the soybean development cycle, more specifically in September 2012 and January 2013. In Figure 2, an initial increase in NDVI can be observed at the time of germination, approximately 8 days after planting, the period in which the seed absorbs $50 \%$ of its volume in water, called the emergence phase (VE). In V1 and V2 (8-24 days after planting), NDVI rapidly increases, rising to 0.67 , which demonstrates the sensitivity of the NDVI index to the addition of phytomass in the initial phase of the crop cycle, as reported by Rizzi \& Rudorff (2007). At 40 days after planting, there is a gradual increase in NDVI (0.808), corresponding to the period in which the fourth trifoliate leaf is fully developed (V5). There is a tendency towards stabilization at 48 days after planting, during the V4 and V5 stages of soybean.

The maximum NDVI $(0.890)$ occurred 72 days after planting, namely at the reproductive stage R5. NDVI indicated increased phytomass in the more advanced phenological stages. The highest NDVI coincided with the period of increased plant development. At this phase, the pod was $3 \mathrm{~cm}$ long in one of the top four nodes of the main stem with a fully developed leaf semi-open flowers, and the plant at its maximum height (Fehr \& Caviness, 1977). A decrease in NDVI began at 88 days after planting, reaching the minimum value on day 112 after planting, stage R8 of the crop, with full maturation. At this phase, senescence of the plants is expressed by a lack of green soybean phytomass at the end of the cycle. Similar results from the NDVI curve for monitoring soybean cultivation were found by Liao et al. (2019).

Variations that occurred in the curve may be associated with weather factors related to harvest, lighting geometry, and the selected day for the generation of the 8day composition (products MOD13Q1 and MYD13Q1), among other factors. Water requirements during the vegetative growth phase are less important compared to the flowering and fruiting phases. Figure 3 shows the real (ET) and potential (PET) evapotranspiration values that occurred in the verified period. Before this, as can be seen, at the beginning of the vegetative growth phase, the average amount of evapotranspirated water was $0.47 \mathrm{~mm}$ (Figure 3). 


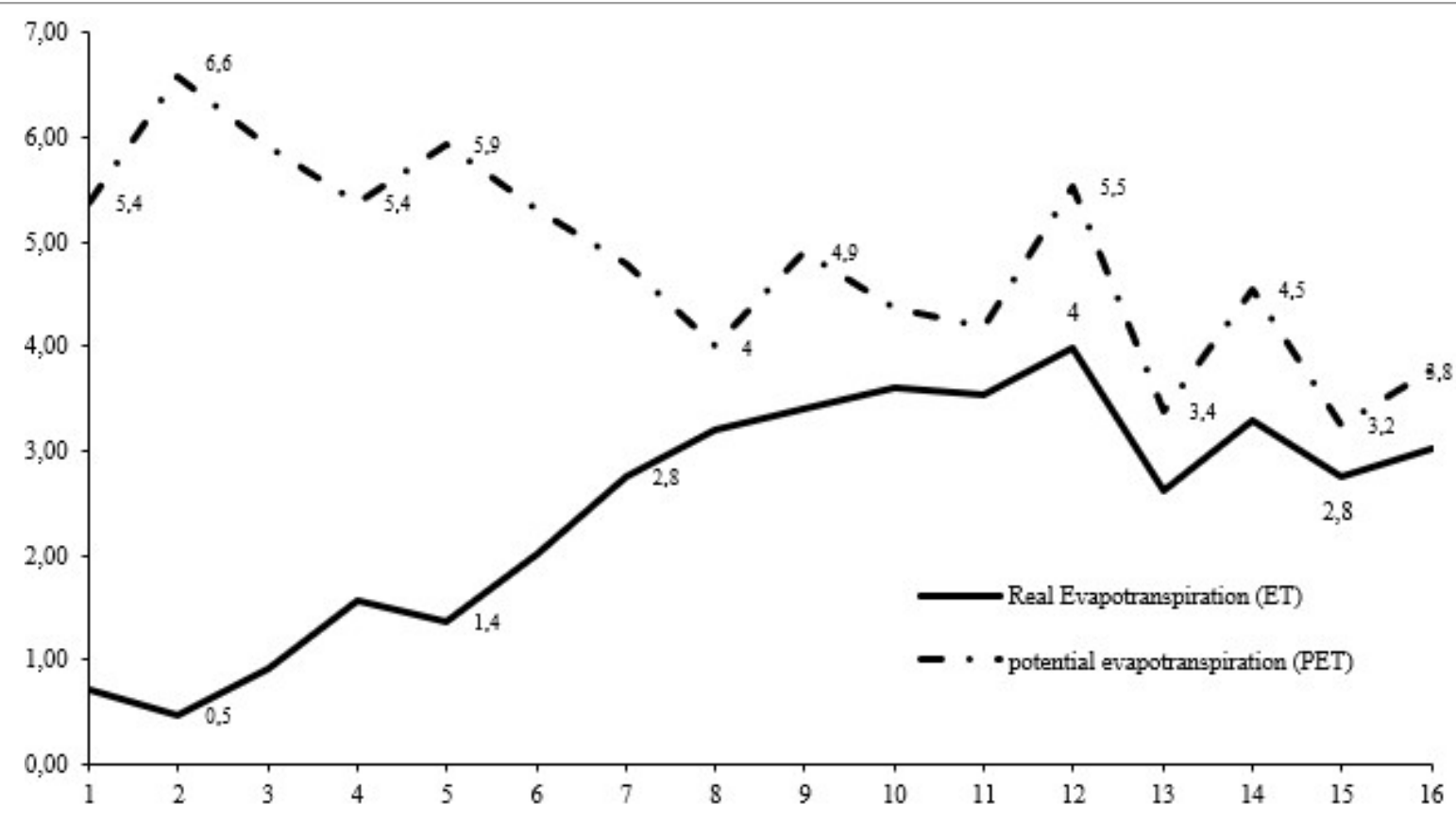

FIGURE 3. Average spectral behavior of ET and PET products (MOD16) for the plots analyzed during the 2012/2013 harvest. The $\mathrm{Y}$-axis is the ET and PET values and the $\mathrm{X}$-axis is the soybean crop cycle.

Excess water or water deficiency between germination and flowering delays vegetative growth and prevents achieving uniformity in the plant population (Camargo, 2006). The availability of water is important during the two main periods of soybean development: germination-emergence and flowering-grain filling. During these periods, there is an increase in the need for water, according to development (Silva, 2011). Water deficiency during flowering (R1-R3) reduces the total number of pods, because soybean is sensitive to water deficiency (Camargo et al., 1986). From this perspective, the flowering and filling stages of grains have the highest water consumption and are therefore the most critical to water deficiency.

From the beginning of the vegetation development phase (V3) to the beginning of grain filling (R5), there was a constant increase in the amount of water evapotranspiration in the plots, which can be seen between
32 to 88 days after planting. Up to 56 days after planting, ET and PET showed opposite values and then maintained a similar pattern (Figure 3). It is worth noting, for example, that 8 days after planting, ET and PET had the opposite behavior, that is, soybean plants had a higher potential of evapotranspiration than real evapotranspiration. This can be attributed to weather influences such as precipitation and temperature, photoperiod, and number of hours of sunlight, among other factors that relate to the radiation being released on the Earth's surface.

The amount of evapotranspiration during the phenological development cycle presented behavior favorable to soybean production for the analyzed plots. In addition to this analysis, information on sunlight hours and temperature (Figure 4) are also important for the development of soybean culture (Rodrigues et al., 2001).

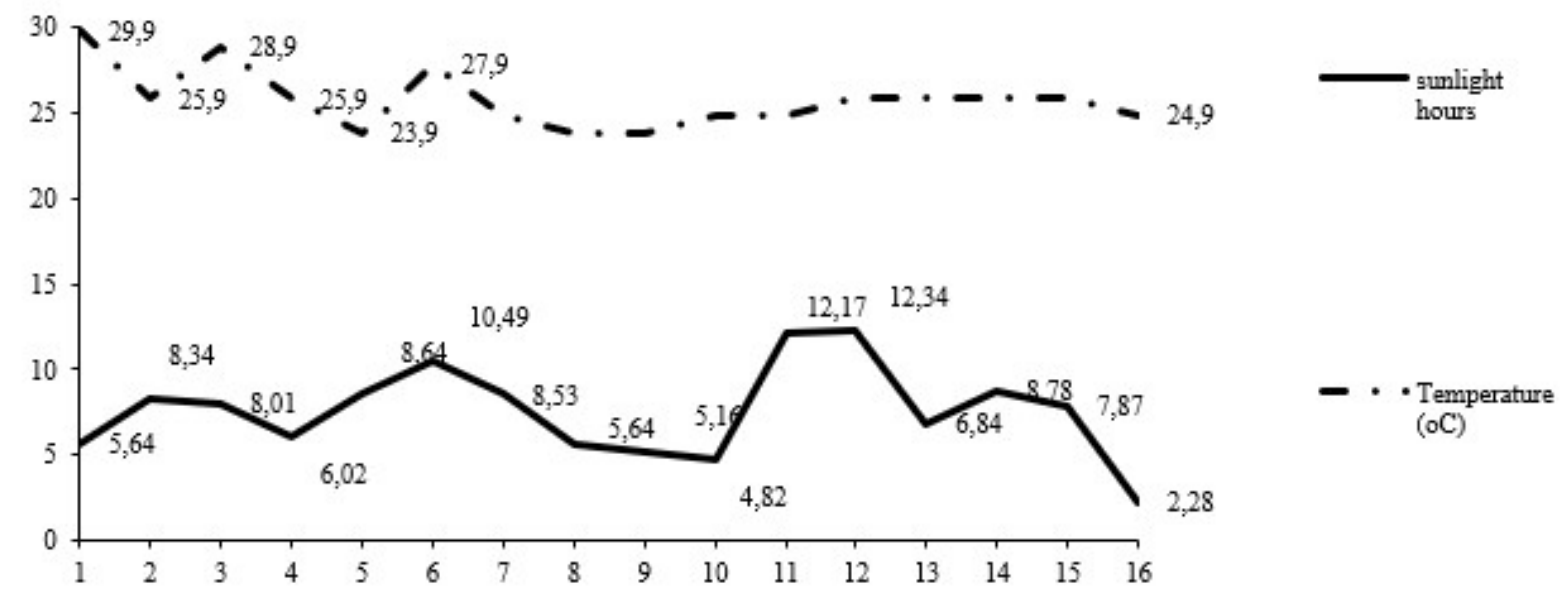

FIGURE 4. Average spectral behavior based on the sunlight hours and temperature for the plots analyzed during the 2012/2013 harvest. The $\mathrm{Y}$-axis is the value of sunlight hours and temperature and the $\mathrm{X}$-axis is the crop cycle. 
Soybeans adapt better in regions where temperatures range from $20^{\circ} \mathrm{C}$ to $30^{\circ} \mathrm{C}$ (Farias et al., 2007). In this study, the minimum average temperature was $23.8^{\circ} \mathrm{C}$ and maximum average temperature was $29^{\circ} \mathrm{C}$, which is favorable to the development of soybean crops. The daily average temperature $\left({ }^{\circ} \mathrm{C}\right)$ data provided by Merra-2 were decisive for the choice of a correction factor for the plant's respiration and were inserted in the calculation of gross dry matter production for each plot during the entire cycle. As for sunlight hours, its value did not follow a pattern and varied throughout the cycle. The maximum number of sunlight hours occurred between 80 and 88 days after planting, during phases R2 to R5, which correspond to the flowering phases and the beginning of grain filling.

\section{Agrometeorological-Spectral Model}

Table 3 shows the estimate of production and productivity calculated by the model and the number of days after planting of each analyzed plot where there was high correlation with the real production values and productivity.

TABLE 3. Final and estimated net production and productivity ( $\mathrm{kg} /$ hectare) for the 10 plots.

\begin{tabular}{cccccc}
\hline Plot & $\begin{array}{c}\text { Real net production } \\
(\mathrm{kg})\end{array}$ & $\begin{array}{c}\text { Net production model } \\
(\mathrm{kg})\end{array}$ & $\begin{array}{c}\text { Prod. Real } \\
(\mathrm{kg} / \mathrm{ha})\end{array}$ & $\begin{array}{c}\text { Prod. Model } \\
(\mathrm{kg} / \mathrm{ha})\end{array}$ & Days after planting \\
\hline 1 & $553,508.00$ & $508,434.94$ & $3,791.15$ & $3,482.43$ & 112 \\
2 & $1,089,822.00$ & $1,071,750.55$ & $3,052.72$ & $3,002.10$ & 96 \\
3 & $554,763.00$ & $525,084.582$ & $3,533.52$ & $3,344.48$ & 112 \\
4 & $479,419.00$ & $450,597.73$ & $3,217.57$ & $3,024,14$ & 104 \\
5 & $434,852.00$ & $438,424.39$ & $3,245.16$ & $3,271.82$ & 112 \\
6 & $837,983.00$ & $853,113.9$ & 3299.14 & 3358.71 & 112 \\
7 & $526,336.00$ & $513,238.4$ & $2,860.52$ & $2,789.33$ & 96 \\
8 & $1,039,132.00$ & $989,488.80$ & 3633.32 & 3459.75 & 112 \\
9 & $404,579.00$ & $421,616.1$ & 3289.26 & 3427.773 & 112 \\
10 & $504,812.00$ & $515,251.3$ & 3321.132 & 3389.811 & 112 \\
\hline
\end{tabular}

Thus, by using the model it is possible to infer the appropriate harvest date for the estimated production and productivity. Rizzi \& Rudorff (2007) scored good results in the productivity estimate while also applying a spectral agronomic model using MODIS images, with an estimate difference ranging from 1 to $228 \mathrm{~kg} \mathrm{ha}^{-1}$ between 2000/2001, 2001/2002, and 2002/2003 harvests. By using the spectral agrometeorological model integrated to a Geographical Information System, for the estimation of soybean productivity, Berka et al. (2003) verified overestimated results with an extra $284 \mathrm{~kg} \mathrm{ha}^{-1}$.

Table 4 presents statistical analyses of the results obtained in the field and by the spectral agrometeorological model. It has been estimated that the results that we calculated and estimated by using the model showed a coefficient of correlation classified as very high net production $(\mathrm{r}=0.99)$ and productivity $(\mathrm{r}=0.84)$, with a coefficient of determination of $\mathrm{R}^{2}=0.99$ and $\mathrm{R}^{2}=0.72$ for production $(\mathrm{p}=<0.0001)$ and productivity $(\mathrm{p}=0.0019)$, respectively. The production and productivity obtained in the field and estimated by the model agree with each other, which corroborates the Willmott $d$ Index presented in Table 4 with 0.99 for net production and 0.96 for productivity. The mean quadratic error (MQE) associated with production was $24,634.36 \mathrm{~kg}$ for an area of 1,942 hectares. Considering that the 10 plots have different areas, productivity in $\mathrm{kg} /$ hectare was calculated individually. Thus, after the calculation of the productivity of each plot, the MQE obtained was $131 \mathrm{~kg} /$ hectare, i.e. 2.18 bags of soybean $(60$ $\mathrm{kg})$ per hectare.

TABLE 4. Yield and statistical analyses of production and productivity results obtained in the field compared to the results of the agrometeorological spectral model in 10 soybean plots in Mato Grosso harvested from 2012/2013.

\begin{tabular}{ccc}
\hline Yield and statistical information & $\begin{array}{c}\text { Net production } \\
(\mathbf{k g})\end{array}$ & $\begin{array}{c}\text { Productivity } \\
\mathbf{( k g ~ h a}^{-1} \mathbf{)}\end{array}$ \\
\hline Field & $6,425,206$ & $3,308,55$ \\
Agrometeorological-Spectral Model & $6,287,000$ & $3,237,38$ \\
Correlation coefficient (r) & 0.99 & 0.84 \\
p value & $<0.0001$ & 0.0019 \\
Coefficient of determination (R $\left.{ }^{2}\right)$ & 0.991 & 0.7202 \\
Regression model & $\mathrm{y}=6704.7047+0.9681 \mathrm{x}$ & $\mathrm{y}=822.4739+0.7317 \mathrm{x}$ \\
MQE (Mean Quadratic Error) & $24,634.36$ & 131.54 \\
Willmott d-test & 0.99 & 0.96 \\
\hline
\end{tabular}


The data obtained in this study corroborate with Gusso et al., (2017), which estimated the soybean production in Mato Grosso in 2005 and 2006 by using MODIS EVI and reported coefficients of determination ranging between 0.91 and 0.98 , with an overall result of $\mathrm{R}^{2}=0.96(\mathrm{p} \leq 0.01)$. The coupled model used by the authors was adjusted to the official statistics. At the local level, spatially distributed data were compared to production data for 422 plantations. The coefficient of determination $\left(\mathrm{R}^{2}=0.87\right)$ confirmed the reliability of the EVI applied in models based on remote sensing for the prediction of soybean production.

\section{CONCLUSIONS}

Projecting and monitoring agricultural crops in the field by objective and direct means remains a challenge. This study contributed to surpassing this challenge, proposing a methodology capable of monitoring the development and quantifying the production and productivity of soybeans in certain parts of the state of Mato Grosso. Analyses of the NDVI vegetation index profile were able to identify and monitor the phenological phases of the cycle and whether crop development takes place within the expected phytomass production. Analysis of the evapotranspiration profile proved efficient for monitoring the water needs of the crop throughout the cycle, providing information for water restriction data, which is important in the calculation of final productivity. The spectral agrometeorological model, based on the methodology by Doorenbos \& Kassam (1979) and developed with the aid of spectral data and the Merra-2 model instead of field variables, was efficient for estimating the net production $(\mathrm{kg})$ and productivity $\left(\mathrm{kg} \mathrm{ha} \mathrm{h}^{-1}\right)$ of soybean. Statistical analyses confirmed that the variables estimated by the agrometeorological spectral model coincide with the variable collected in the field. For the study area, the estimation error of the agrometeorological spectral model was low, at 2.18 bags (around $120 \mathrm{~kg}$ ) of soybean per hectare. Therefore, for the study area, the proposed methodology was consistent and objective for estimating the production and productivity of soybean cultivation.

\section{REFERENCES}

Artuzo FD, Foguesatto CR, Souza ARL, Silva LX (2018) Costs management in maize and soybean production. Review of Business Management 20(2):273294. DOI: http://dx.doi.org/10.7819/rbgn.v20i2.3192

Battisti R, Sentelhas PC, Pilau FG, Wollmann CA (2013) Eficiência climática para as culturas da soja e do trigo no estado do Rio Grande do Sul em diferentes datas de semeadura. Ciencia Rural 43(3):390-396. DOI: http://dx.doi.org/10.1590/S0103-84782013000300003

Berka LMS, Rudorff BFT, Shimabukuro YE (2003) Soybean yield estimation by an agrometeorological model in a GIS. Scientia Agricola 60(3):433-440. DOI: http://dx.doi.org/10.1590/S0103-90162003000300003

Betbeder J, Fieuzal R, Baup F (2016) Assimilation of LAI and dry biomass data from optical and SAR images into an agro-meteorological model to estimate Soybean Yield. IEEE Journal of Selected Topics in Applied Earth Observations and Remote Sensing 9(6):2540-2553. DOI: http://dx.doi.org/10.1109 / JSTARS.2016.2541169
Camargo MBP (2006) Relações entre produtividade e exigências bioclimáticas da Soja. Visão Agrícola 5(1):67-69.

Camargo MBP de, Brunini O, Miranda MAC de (1986)

Modelo agrometeorológico para estimativa da produtividade para a cultura da soja no Estado de São Paulo. Bragantia 45(2):279-292.

Companhia Nacional de Abastecimento - CONAB. Acompanhamento da Safra Brasileira de Graõs: volume 4 - Safra 2016/17 - Nono levantamento, junho 2017. Brasília: Conab, 2017. 170 p.

Doorenbos J, Kassan AH (1994) Efeitos da água no rendimento das culturas. FAO, 212 p. Irrigação e Drenagem, 33.

Doorenbos J, Kassam AH (1979) Yiels response to water. Rome, FAO, 306 p. Irrigation and Drainage Paper, 33.

Farias JRB, Nepomuceno AL, Neumaier N (2007)

Ecofisiologia da soja. Embrapa Soja (48):1-8.

Fehr WR, Caviness CE (1977) Stages of soybean development. Special Report (80):1-12.

Gajić B, Kresović B, Tapanarova A, Životić L, Todorović M (2018) Agricultural water management (210):224-231. DOI: https://doi.org/10.1016/j.agwat.2018.08.002

Gusso A, Ducati JR, Veronez MR, Arvor D, Junior LGS (2013) Spectral model for soybean yield estimate using MODIS/EVI Data. International Journal of Geosciences 4(9):1233-1241. DOI: 10.4236/ijg.2013.49117

Gusso A, Arvor D, Ducati JR (2017) Model for soybean production forecast based on prevailing physical conditions. Pesquisa Agropecuária Brasileira 52(2):95103. DOI: http://dx.doi.org/10.1590/s0100204x2017000200003

Lacasa A, Ovando G, Bressanini L, Martínez J, Díaz G, Miranda C (2018) Soybean crop coverage estimation from NDVI images with different spatial resolution to evaluate yield variability in a plot. Isprs Journal of Photogrammetry And Remote Sensing (146):531-547. DOI: https://doi.org/10.1016/j.isprsjprs.2018.10.018

Liao C, Wang J, Dong T, Shang J, Liu J, Song Y (2019) Using spatio-temporal fusion of Landsat-8 and MODIS data to derive phenology, biomass and yield estimates for corn and soybean. Science of the total environment (650):1707-1721. DOI:

http://dx.doi.org/10.1016/j.scitotenv.2018.09.308

Mercante E, Lima LEP, Justina DDD, Uribe-Opazo MA, Lamparelli RAC (2012) Detection of soybean planted areas through orbital images based on culture spectral dynamics. Engenharia Agrícola 32 (5):920-931. DOI: http://dx.doi.org/10.1590/S0100-69162012000500011

Meshesha DT, Abeje M (2018) Developing crop yield forecasting models for four major Ethiopian agricultural commodities. Remote Sensing Applications: Society and Environment (11):83-93 DOI: https://doi.org/10.1016/j.rsase.2018.05.001 
Nascimento WF, Costa JS, Peixoto PP, Duarte NDL (2018) Efeitos da temperatura sobre a soja e milho no Estado de Mato Grosso do Sul. Investigación Agraria 20 (1):30-37. DOI: http://dx.doi.org/10.18004/investig.agrar.2018.junio.30-37

Ovando G, Sayago S, Bocco M (2018) Evaluating accuracy of DSSAT model for soybean yield estimation using satellite weather data. Isprs Journal of Photogrammetry And Remote Sensing (138):208-217. DOI: https://doi.org/10.1016/j.isprsjprs.2018.02.015

Pereira AR, Angelocci LR, Sentelhas PC (2007) Meteorologia agrícola. Piracicaba, ESALQ, 192 p.

Rizzi R, Rudorff BFT (2007) Imagens do sensor MODIS associadas a um modelo para estimar a produtividade de soja. Pesquisa Agropecuária Brasileira 42 (1):73-80. DOI: http://dx.doi.org/10.1590/S0100-204X2007000100010

Rodrigues OD, Didonet AD, Lhamby JCB, Bertagnolli PF, Luz JS (2001) Resposta quantitativa do florescimento da soja à temperatura e ao fotoperíodo. Pesquisa Agropecuária Brasileira 36(3):431-437. DOI: https://dx.doi.org/10.1590/S0100-204X2001000300006
Salimon C, Anderson L (2017) How strong is the relationship between rainfall variability and Caatinga productivity? A case study under a changing climate. Anais da Academia Brasileira de Ciências 90(2):2121-2127. DOI: http://dx.doi.org/10.1590/00013765201720170143

Silva DF (2011) Uso de modelos agrometeorológicos de estimativa de produtividade e de risco climático para a soja no vale do médio Paranapanema - SP. Dissertação Mestrado, Instituto Agronômico de Campinas.

Willmott CJ, Steven GA, Davis RE, Feddema JJ, Klink KM, Legates DR, O'Donnell J, Rowe CM (1985) Statistics for the evaluation and comparison of models. Journal of Geophysical Research 90 (5):8995-9005. DOI: https://doi.org/10.1029/JC090iC05p08995

Zeng L, Wardlow BD, Wang R, Shan J, Tadesse T, Hayes MJ, Li D (2016) A hybrid approach for detecting corn and soybean phenology with time-series MODIS data. Remote Sensing of Environment (181):237-250. DOI: https://doi.org/10.1016/j.rse.2016.03.039 